\title{
Effect of Mechanical Properties On Light Weight Sustainable Concrete With The Use of Waste Coconut Shell As Replacement For Coarse Aggregate
}

Karthiga Shenbagam Natarajan ( $\sim$ karthis47@gmail.com )

Bannari Amman Institute of Technology Department of Civil Engineering https://orcid.org/0000-00024921-8487

Dhivya Ramalingasekar

Bannari Amman Institute of Technology Department of Civil Engineering

Sushmitha Palanisamy

Bannari Amman Institute of Technology Department of Civil Engineering Mohanraj Ashokan

Bannari Amman Institute of Technology Department of Civil Engineering

\section{Research Article}

Keywords: Concrete, tremendous, proportions, elasticity

Posted Date: July 26th, 2021

DOI: https://doi.org/10.21203/rs.3.rs-625366/v1

License: (9) This work is licensed under a Creative Commons Attribution 4.0 International License.

Read Full License 


\section{Abstract}

Concrete is one of the most important material that is used in the construction industry all around the world. A larger part of the capacity in concrete is generally employed by the coarse aggregate. Due to the tremendous use of coarse aggregate in the construction industry the material is getting degraded. In order to preserve the natural material, we are in search of an alternate material that can be used in concrete instead of the original one. So in this research work a try has been attempted to study the mechanical behaviour of light weight concrete when we use coarse aggregate as waste coconut shell inside concrete. To improve the strength of concrete we also use the sisal fibers in various proportions ranging between $1 \%$ to $5 \%$ in accordance to the binder weight. After the mechanical properties tests such as the compression test, spilt tensile strength, flexural test, modulus of elasticity test, impact resistant test were conducted finally it was concluded that there was increment in the compression strength up to $5 \%$, tensile strength was increased to $17 \%$ elastic modulus to $7 \%$ when the fiber content used was $3 \%$. Thus with the use of these waste materials it was found that the concrete's strength gets increased and it leads to the formation of sustainable concrete thus reducing the pollution in the environment.

\section{Introduction}

Concrete is the world's second most disbursed component and is a widely utilized building material (Meyer 2009). Concrete production tops ten billion tonnes each year and due to global infrastructural developments, the use of concrete has increased. To attain a sustainable and eco-friendly structure, the construction industry needs clean and green concrete solutions. Coconut shell is a prominent waste product of humid agricultural industries such as India (Prakash 2017). In the building industry, coconut shell is recycled and is frequently discarded as waste. A novel strategy in concrete production is the use of coarse aggregate as a coconut shell in the manufacture of lightweight concrete (Gunasekaran et al. 2017). In India, coconut shell contributes to approximately sixty percent of total home garbage, providing a huge disposal challenge. Coconut shell is generally dumped as garbage once the coconut is tattered from the shell. The waste coconut shell can be crushed to the desired extent and reused as coarse aggregate to manufacture light weight concrete. This form of concrete has the additional profit of reducing the cost of building material.

The cement manufacturing industry alone accounts for at least five percent of human caused emissions, accounting for twenty five percent of total world carbon dioxide emissions from the manufacturing sector. Furthermore, research has indicated that cement manufacture directly contributes to eighty five percent of carbon dioxide emissions emitted during the lifespan of concrete buildings (Habert et al. 2009 and Lim et al. 2018). Comparing with the standard concrete the light weight concrete is twenty to twenty five percent lighter (Lo and Cui 2002). Structural light weight concrete has more flexibility, minimum dead weight, strong seismic response, and low cost for foundation (Nagarajan et al 2020). The primary drawback of light weight concrete is it requires more cement to produce the same strength as normal concrete. This drawback can be solved by replacement of a portion of cement with pozzolanic manufacturing waste (Shafigh et al 2013). 
On the other hand, adding fibers to construction materials has been a practice in many regions. Natural fibers used as subordinate reinforcement in concrete are more environmentally friendly substitute to synthetic fibers (Rokbi et al. 2019). Sisal fibers include a high percentage of cellulose, which gives greater tensile strength, and they not captivate water. Because of its low cost, thermal properties, adequate tensile strength, excellent durability, scratch resistance, and availability the sisal fiber is the most often used natural fiber in the construction industry.

In this study, a try has been attempted to study the mechanical behavior of light weight concrete when we use coarse aggregate as a waste coconut shell inside concrete. To improve the strength of concrete we also use the sisal fibers in various proportions ranging between 1-5\% in accordance to the binder weight. After the mechanical property tests such as the compression test, spilt tensile strength, flexural test, modulus of elasticity test, impact resistant test was conducted. This experimental work was performed at the Bannari Amman Institute of Technology in Sathyamangalam, Tamil Nadu, India.

\section{Materials And Methods}

\section{Materials}

In this investigation, ordinary Portland cement (OPC) of Grade 53 that met the standards of IS: 12269 1987 was employed. Its specific surface area is $345 \mathrm{~m}^{2} / \mathrm{kg}$ and specific gravity of 3.15 . The cement's initial and final setting periods are 75 minutes and 150 minutes, respectively. The fine aggregate used is river sand meeting the requirements of Zone II. It has a specific gravity of 2.38 and a modulus of fineness of 2.95. The Coconut shell was collected from a local coconut grove, located near Sathyamangalam, Tamilnadu, India. The Coconut shell was then broken into smaller pieces and sieved. Coconut shells ranging in size from 12.5 to $4.75 \mathrm{~mm}$ were utilised for coarse aggregate. Then it is splashed by means of fresh water and then dried out by natural drying method. The Physical features of the Coconut shell are itemized in Table 1. Sisal fibre was brought from SP Grade Natural at Gobichettipalayam, Erode district, Tamilnadu, India. The properties of sisal fibre are itemized in Table 2. 
Table 1

Physical properties of Coconut Shell

\begin{tabular}{|ll|}
\hline Properties & Values obtained \\
\hline Size of the aggregate $(\mathrm{mm})$ & 12.5 to 4.75 \\
\hline Thickness of the aggregate $(\mathrm{mm})$ & $3.5-8.5$ \\
\hline Specific gravity & 1.21 \\
\hline Fineness modulus (FM) & 6.20 \\
\hline Water absorption (\%) & 23 \\
\hline Bulk density $\left(\mathrm{g} / \mathrm{cm}^{3}\right)$ & 0.68 \\
\hline Abrasion value $(\%)$ & 2.1 \\
\hline Impact value $(\%)$ & 8.0 \\
\hline
\end{tabular}

Table 2

Sisal fibre properties

\begin{tabular}{|ll|}
\hline Properties & Values obtained \\
\hline Diameter of the fibre $(\mathrm{mm})$ & $0.3-0.4$ \\
\hline Length $(\mathrm{mm})$ & 350 \\
\hline Density $(\mathrm{g} / \mathrm{cc})$ & 1.50 \\
\hline Water absorption (\%) & 8 \\
\hline Modulus of elasticity (Mpa) & $15500-16500$ \\
\hline Tensile strength (Mpa) & $550-650$ \\
\hline
\end{tabular}

\section{Mix proportion and procedure}

According to the $\mathrm{ACl}$ the specimen is prepared for the investigation. The cement and also fine aggregate were retained at same levels at $465 \mathrm{~kg} / \mathrm{m}^{3}$ and $755 \mathrm{~kg} / \mathrm{m}^{3}$. Sisal fibres were added to the concrete based on weight of the cement by $1 \%, 2 \%, 3 \%, 4 \%$ and $5 \%$. Water to cement ratio is kept constant at 0.35 . The proportion of all the mixtures were listed on Table 3. For about 4 minutes, in the rotating drum mixer, the Coconut shell aggregate and river sand were mixed to designate the classification of mixing followed by adding of cement for furthermore 5 minutes. Then, water is included into the rotating drum and it is mixed for further 9 minutes. Lastly, sisal fibres are uniformly mixed to the sample and the mixture is positioned into moulds and compacted for the test. After 24 hours, it demoulded and cured until the testing date. 
Table 3

Mix proportion of the proposed sample

\begin{tabular}{|llllll|}
\hline Mixture & $\begin{array}{l}\text { Cement } \\
\left(\mathbf{k g} / \mathrm{m}^{3}\right)\end{array}$ & $\begin{array}{l}\text { Fine aggregate } \\
\left(\mathbf{k g} / \mathrm{m}^{3}\right)\end{array}$ & $\begin{array}{l}\text { Coconut shell } \\
\text { aggregate } \\
\left(\mathbf{k g} / \mathrm{m}^{3}\right)\end{array}$ & $\begin{array}{l}\text { Water/binder } \\
\text { ratio }\end{array}$ & $\begin{array}{c}\text { Sisal } \\
\text { fiber } \\
\text { (\%) }\end{array}$ \\
\hline $\begin{array}{l}\text { Coconut } \\
\text { shell 1 }\end{array}$ & 465 & 755 & 335 & 0.35 & $1 \%$ \\
\hline $\begin{array}{l}\text { Coconut } \\
\text { shell 2 }\end{array}$ & 465 & 755 & 335 & 0.35 & $2 \%$ \\
\hline $\begin{array}{l}\text { Coconut } \\
\text { shell 3 }\end{array}$ & 465 & 755 & 335 & 0.35 & $3 \%$ \\
\hline $\begin{array}{l}\text { Coconut } \\
\text { shell 4 }\end{array}$ & 465 & 755 & 335 & 0.35 & $4 \%$ \\
\hline $\begin{array}{l}\text { Coconut } \\
\text { shell 5 }\end{array}$ & 465 & 755 & 335 & 0.35 & $5 \%$ \\
\hline
\end{tabular}

\section{Testing methods}

According to ASTM C143, the slump test was performed before casting the specimens. After casting, the specimens were demoulded after 24 hours. Using $150 \mathrm{~mm}$ cube specimens, the compressive strength was determined according to ACl. Modulus of elasticity is determined with two cylinders of diameter 150 $\mathrm{mm}$ and height $300 \mathrm{~mm}$ by ASTM C469. According to ASTM C496, the 28-day split tensile strength is determined with three cylinders of diameter $100 \mathrm{~mm}$ and height $200 \mathrm{~mm}$. As per ASTM D790, three prisms of size $100 \mathrm{~mm} \times 100 \mathrm{~mm} \times 500 \mathrm{~mm}$ were used to measure 28-day flexural strength. The capacity of the compressive testing machine is $1500 \mathrm{kN}$ and the loading rate is $2.4 \mathrm{kN} / \mathrm{s}$. Finally, the impact test was performed by adopting the drop hammer technique on concrete discs of diameter $150 \mathrm{~mm}$ and height $63 \mathrm{~mm}$.

\section{Results And Discussion}

\section{Slump Test}

The level of the concrete structure is determined not only by the element quality, and also by flowability of the concrete mix during travel, installation, and during the compaction. The workability is a quality that indicates the effort necessary to work on fresh concrete with the minimum deterioration of consistency. (Mehta and Monteiro 2006) stated that for satisfactory compaction and finishing, a slump of 50 to 75 was sufficient for lightweight concrete. (Atis 2003) found that when the number and length of jute fibres expanded, the workability of mortar and cement paste was diminished. In this study, the water was fixed for all mixtures. The addition of sisal fiber has reduced the value of the slump. Figure 1 shows that with 
the inclusion of sisal fibres, the slump value has been reduced. The inclusion of $1 \%, 2 \%, 3 \%, 4 \%$ and $5 \%$ sisal fibre reduced the slump value by $8 \%, 22 \%, 29 \%, 51 \%$ and $63 \%$ respectively. As a result, the combination containing 1 percent sisal fibre had the low droop but can be sufficiently consolidated.

\section{Compressive Strength Test}

Table 4 shows that the compressive strength values of proposed concrete mixes at twenty-eight days for various sisal fibre concentrations. The inclusion of sisal fibre boosted strength in this investigation. The combination containing 3 percent sisal fibre had the maximum compressive strength among the different percentages of incorporated sisal fibre. (Prakash et al. 2019) obtained greater than $35 \mathrm{MPa}$ compressive strength in proposed concrete. Furthermore, by introducing polypropylene fibre, (Prakash et al. 2020) increased the compressive strength of proposed concrete to above $36 \mathrm{MPa}$. With the inclusion of sisal fibre, furthermore 5 percent increase was obtained in this research. When the load gets increased, it will induct crack expansion in the concrete. This study exposed that with the inclusion of sisal fibres, the compressive strength of Coconut shell concrete gets increased up to $5 \%$.

Table 4

Compressive strength of proposed concrete

\begin{tabular}{|l|l|}
\hline Mixture with inclusion of sisal fibre & Compressive strength (Mpa) \\
\hline $1 \%$ & 35.8 \\
\hline $2 \%$ & 36.9 \\
\hline $3 \%$ & 37.8 \\
\hline $4 \%$ & 35.6 \\
\hline $5 \%$ & 32.6 \\
\hline
\end{tabular}

\section{Split Tensile Strength Test}

The most significant property of concrete is tensile strength which is vulnerable to cracking due to tensile loading, with its deadweight. Thus, by conducting splitting tensile and flexural strength tests the concrete's tensile strength is determined. In general, lightweight concrete has weak tensile strength. Steel fiber-reinforced coconut shell concrete demonstrated a substantial rise in split tensile strength. The Polypropylene fibre raised coconut shell concrete's split tensile strength by twenty-two percent. (Prakash et al. 2020). The value of split tensile strength of sisal fiber-reinforced concrete is shown in Table 5. The use of sisal fibre improves the overall strength of proposed concrete. By including $3 \%$ sisal fibre, it is resulted that maximum increase in split tensile strength of $17 \%$ is obtained. By adding coir fibre to coconut shell concrete, it enhances the split tensile strength considerably (Mandal et al. 2018) 
Table 5

Split tensile strength of the concrete

\begin{tabular}{|ll|}
\hline Mixture with inclusion of sisal fibre & Split tensile strength (Mpa) \\
\hline $1 \%$ & 3.05 \\
\hline $2 \%$ & 3.50 \\
\hline $3 \%$ & 3.81 \\
\hline $4 \%$ & 3.45 \\
\hline $5 \%$ & 3.10 \\
\hline
\end{tabular}

\section{Modulus of Elasticity}

The Concrete's modulus of elasticity is a significant mechanical constraint that represents the material's capacity to distort elastically. Lightweight aggregates feature larger pores and are stiffer than traditional aggregates. The Concrete's modulus of elasticity varies sisal fibre concentrations are shown in Table 6 . The inclusion of sisal fibre to the coconut shell concrete resulted in small increase of elastic modulus. After adding up to 3 percent fibre, the modulus of elasticity increased, but after adding 4 percent and 5 percent fibre, it dropped. The inclusion of sisal fibres to coconut shell concrete enhanced its flexural strength by $7 \%$ in this study. The inclusion of sisal fibre to Coconut shell concrete at 1 percent, 2 percent, and 3 percent enhanced its flexural strength by around $1 \%, 4 \%$, and $7 \%$, respectively. However, the inclusion of 4 percent and 5 percent fibre reduced the proposed concrete's flexural strength marginally.

Table 6

Concrete's modulus of elasticity

\begin{tabular}{|ll|}
\hline Mixture with addition of sisal fibre & Modulus of Elasticity (Mpa) \\
\hline $1 \%$ & 15180 \\
\hline $2 \%$ & 15350 \\
\hline $3 \%$ & 15780 \\
\hline $4 \%$ & 15670 \\
\hline $5 \%$ & 15430 \\
\hline
\end{tabular}

\section{Impact Strength Test}

Impact is the sudden load created on the specimen. Cementitious compounds with crop fibre produce similar results as of synthetic fibres. By increasing the quantity of banana fibre in concrete enhanced its impact resistance (Sudarisman et al. 2015). The impact characteristics of a cement mortar panel reinforced with jute fibre were enhanced by (Zhou et al. 2013). Because the fibres are covered over 
fissures, the impact energy may be captivated, and crack progression inside the concrete is stopped. The impact energy of the proposed specimens rose by 36 percent, 50 percent, 70 percent, 85 percent, and 96 percent after adding 1 percent, 2 percent, 3 percent, 4 percent, and 5 percent fibre, respectively, in this investigation.

\section{Result}

From this investigation, it can be concluded that with inclusion of sisal fibre up-to 3 percent shows good increment in the strength properties. It is obtained that there was an increment in the compression strength up to $5 \%$, tensile strength was increased to $17 \%$ elastic modulus to $7 \%$ when the fiber content used was $3 \%$. Thus, with the use of these waste materials, it was found that the concrete's strength gets increased and it leads to the formation of sustainable concrete thus reducing the pollution in the environment. It also increased flexural strength substantially. Concrete's modulus of elasticity was somewhat enhanced. The fibre addition leads to a substantial inclusion in impact energy. Coconut shell is a renewable and certainly accessible resource, utilized as an biodegradable construction material. The use of sisal fibre improved the mechanical qualities of Coconut shell concrete, making it suitable for structural purposes.

\section{Declarations}

\section{Ethical Approval}

This is the work done by me and the PG students, it is not published anywhere else by us.

\section{Consent to Participate}

All the authors of this paper have given their consent to participate and act as one of the authors.

\section{Consent to Publish}

I, the author, give my consent for the publication of identifiable details, which can include photograph(s) or case history and details within the text

\section{Authors Contributions}

Karthiga Shenbagam Natarajan, Dhivya Ramalingasekar, Sushmita Palanisamy, Mohanraj Ashokan, all four authors have equally contributed for this work.

\section{Funding}

There is no funding required for this work

\section{Competing Interests}


There is no financial aid available

\section{Availability of data and materials}

All the necessary data are given in the paper in detail

\section{References}

1. Ali M, Liu A, Sou H, Chouw N (2012) Mechanical and dynamic properties of coconut fibre reinforced concrete. Constr Build Mater 30:814-825. https://doi.org/10.1016/j.conbu ildma t.2011.12.068

2. Atiş CD (2003) High-volume fly ash concrete with high strength and low drying shrinkage. J Mater Civ Eng 15:153-156. https://doi. org/10.1061/(asce)0899-1561(2003)15:2(153)

3. Gunasekaran K, Pennarasi G, Soumya S, Shruti L (2017) All-in-one about a momentous review study on coconut shell as coarse aggregate in concrete. Int J Civ Eng Technol 8:1049-1060

4. Habert G, Roussel N (2009) Study of two concrete mix-design strategies to reach carbon mitigation objectives. Cem Concr Compos 31:397-402. https://doi.org/10.1016/j.cemco ncomp.2009.04.001

5. Lim JLG, Raman SN, Lai F-C et al (2018) Synthesis of nano cementitious additives from agricultural wastes for the production of sustainable concrete. J Clean Prod 171:1150-1160. https://doi. org/10.1016/j.jclep ro.2017.09.143

6. Lo TY, Cui HZ (2002) Properties of green lightweight aggregate concrete. In: International workshop on sustainable development and concrete technology, New York, USA, pp 113-118

7. Mandal B, Tiwari S, Ghimire S, Tiwari A (2018) Mechanical properties of concrete with partial replacement of coarse aggregates by coconut shells and reinforced with coconut fibre. J Build Mater Struct 5:227-238. https://doi.org/10.5281/zenod 0.25388 31

8. Mehta NK, Monteiro PJM (2006) Concrete: microstructure, properties, and materials. McGraw-Hill, New York

9. Meyer C (2009) The greening of the concrete industry. Cem Concr Compos 31:601-605. https://doi.org/10.1016/j.cemco ncomp.2008.12.010

10. Nagarajan D, Rajagopal T, Meyappan N (2020) A comparative study on prediction models for strength properties of LWA concrete using artificial neural network. Revista de la construcción. https://doi. org/10.7764/rdlc.19.1.103-111

11. Prakash R (2017) Study on properties of coconut shell aggregate and compressive strength of coconut shell concrete. Int J Eng Technol Sci Res 4:592-602

12. Prakash R, Thenmozhi R, Raman S (2019) Mechanical characterisation and flexural performance of eco-friendly concrete produced with fly ash as cement replacement and coconut shell coarse aggregate. Int J Environ Sustain Dev 18:131. https://doi.org/10.1504/ijesd.2019.09949 1

13. Prakash R, Thenmozhi R, Raman SN et al (2020a) An investigation of key mechanical and durability properties of coconut shell concrete with partial replacement of fly ash. Struct Concr. https://doi. org/10.1002/suco.20190 0162 
14. Rokbi M, Baali B, Rahmouni ZEA, Latelli H (2019) Mechanical properties of polymer concrete made with jute fabric and waste marble powder at various woven orientations. Int J Environ Sci Technol 16:5087-5094. https://doi.org/10.1007/s1376 2-019-02367-7

15. Shafigh P, Alengaram UJ, Mahmud HB, Jumaat MZ (2013) Engineering properties of oil palm shell lightweight concrete containing fly ash. Mater Des 49:613-621. https://doi.org/10.1016/j.matde s.2013.02.004

16. Sudarisman, Muhammad BNR, Prabowo AB (2015) Impact behavior of apus bamboo (Gigantochloa apus) fiber/epoxy green composites. Appl Mech Mater 758:83-87. https://doi.org/10.4028/www. scien tific.net/amm.758.83

17. Zhou X, Ghaffar SH, Dong W et al (2013) Fracture and impact properties of short discrete jute fibrereinforced cementitious composites. Mater Des 49:35-47. https://doi.org/10.1016/j.matdes.2013.01.029

\section{Figures}

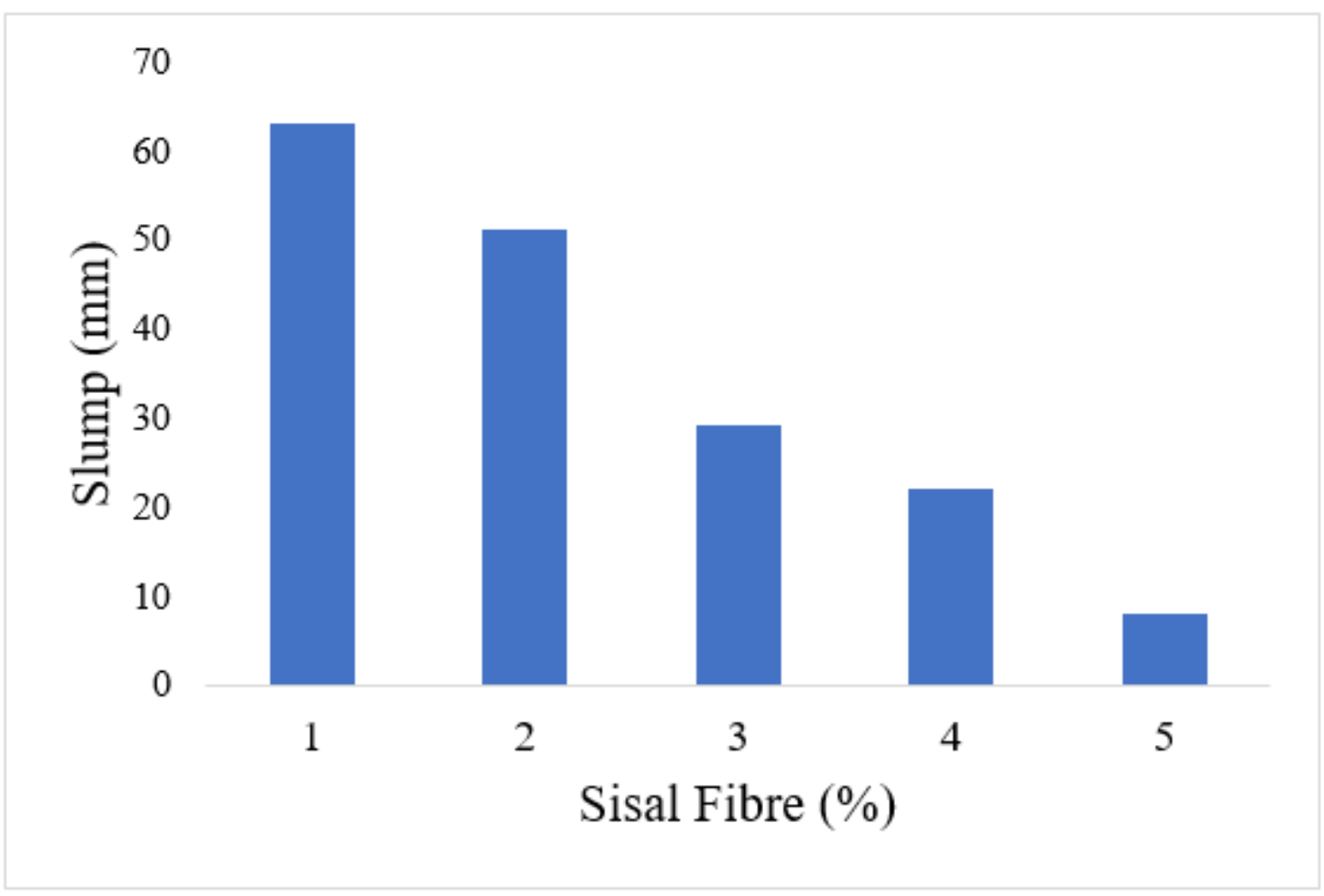

\section{Figure 1}

Slump value with addition of Sisal fibre 


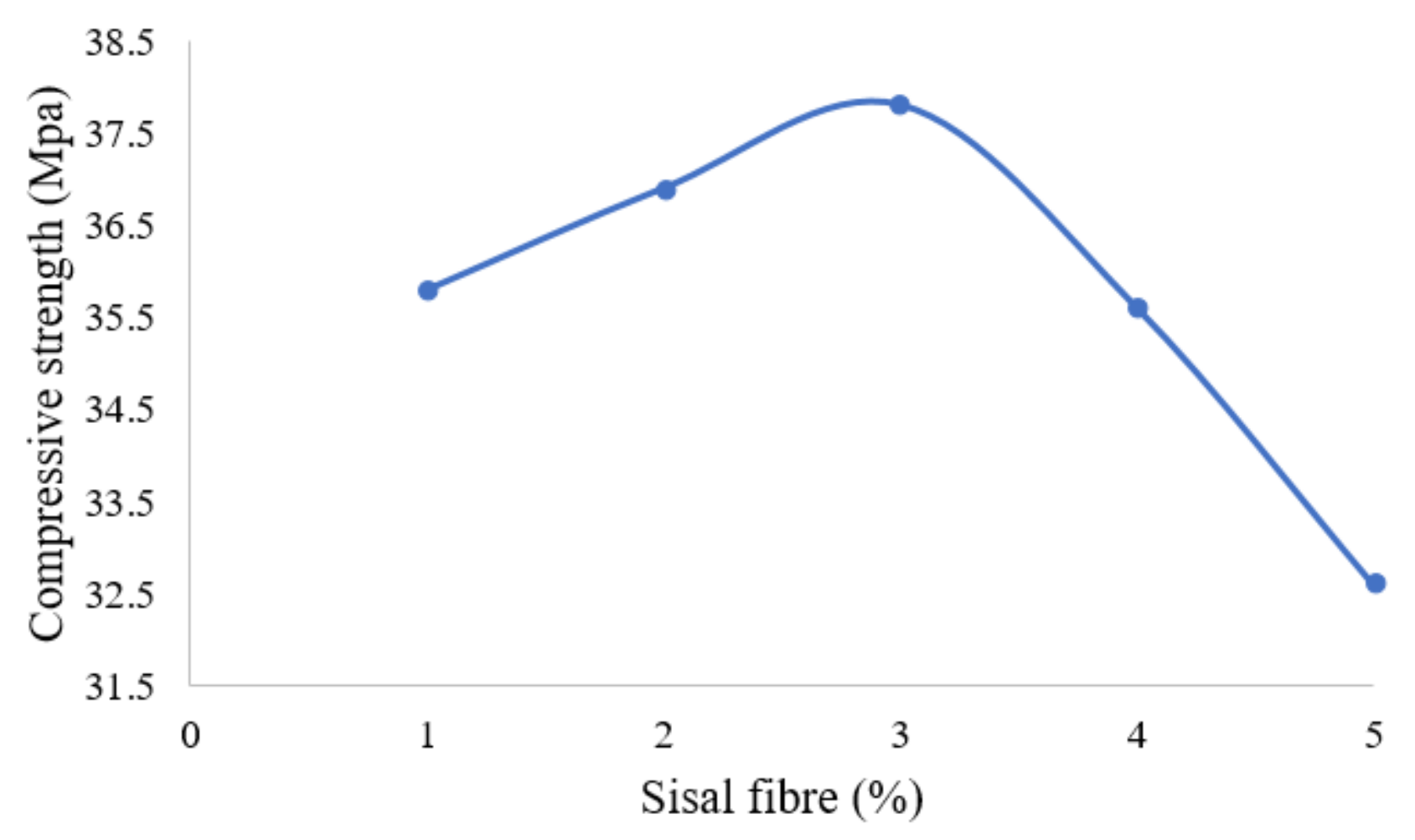

Figure 2

Compressive strength with inclusion of sisal fibre

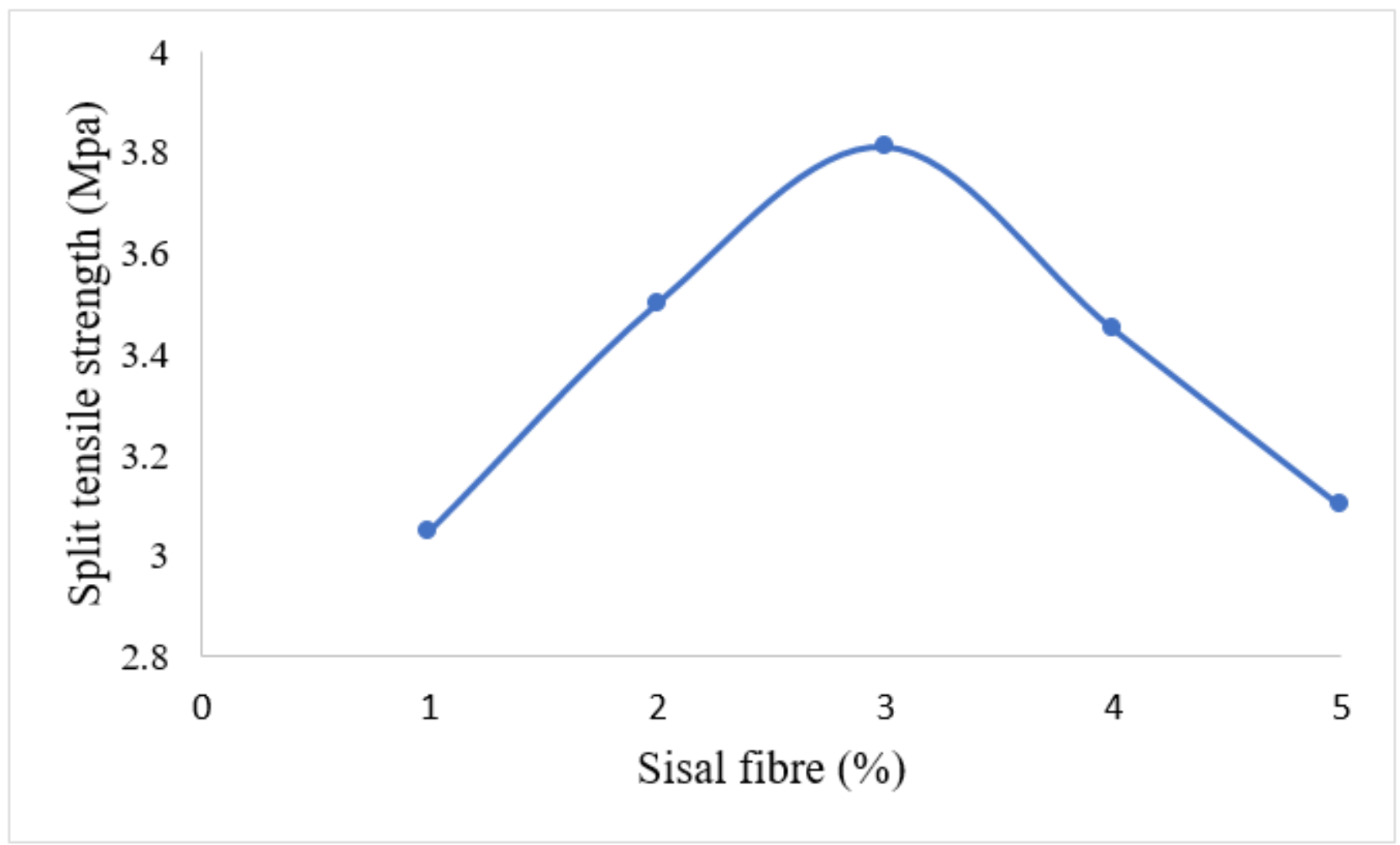

Figure 3 
Split tensile strength with addition to sisal fibre

Page 12/12 